\title{
Study on Plastic Coated Overburnt Brick Aggregate as an Alternative Material for Bituminous Road Construction
}

\author{
Dipankar Sarkar, ${ }^{1}$ Manish Pal, ${ }^{1}$ and Ashoke K. Sarkar ${ }^{2}$ \\ ${ }^{1}$ Department of Civil Engineering, NIT Agartala, Tripura 799046, India \\ ${ }^{2}$ Department of Civil Engineering, BITS Pilani, Rajasthan 333031, India \\ Correspondence should be addressed to Dipankar Sarkar; dipankarnita@gmail.com
}

Received 20 April 2016; Accepted 12 July 2016

Academic Editor: Amit Bandyopadhyay

Copyright (C) 2016 Dipankar Sarkar et al. This is an open access article distributed under the Creative Commons Attribution License, which permits unrestricted use, distribution, and reproduction in any medium, provided the original work is properly cited.

\begin{abstract}
There are different places in India where natural stone aggregates are not available for constructional work. Plastic coated OBBA can solve the problem of shortage of stone aggregate to some extent. The engineers are always encouraged to use locally available materials. The present investigation is carried out to evaluate the plastic coated OBBA as an alternative material for bituminous road construction. Shredded waste plastics are mixed with OBBA in different percentages as $0.38,0.42,0.46,0.50,0.54$, and 0.60 of the weight of brick aggregates. Marshall Method of mix design is carried out to find the optimum bitumen content of such bituminous concrete mix prepared by plastic coated OBBA. Bulk density, Marshall Stability, flow, Marshall Quotient, ITS, TSR, stripping, fatigue life, and deformations have been determined accordingly. Marshall Stability value of 0.54 percent of plastic mix is comparatively higher than the other mixes except 0.60 percent of plastic mix. Test results are within the prescribed limit for 0.54 percent of plastic mix. There is a significant reduction in rutting characteristics of the same plastic mix. The fatigue life of the mix is also significantly higher. Thus plastic coated OBBA is found suitable in construction of bituminous concrete road.
\end{abstract}

\section{Introduction}

There are different states in India where rocks are not locally available. The stone aggregates need to be transported from other places for constructional work. Modified overburnt brick aggregate (OBBA) can solve the problem of shortage of stone aggregate to some extent. Bricks are produced from the locally available soil by burning the molded earth to desired forms. Approximately 5-10\% of bricks manufactured in modern kilns are rejected because of their nonconformity with relevant specifications $[1,2]$. These bricks are overburnt, distorted in shape, and considered as waste. OBBA is produced from distorted bricks by manual or mechanical crushing.

The properties of plain OBBA are weaker compared to natural stone aggregate. It has lower specific gravity, high pore rate and thus high water absorption, and lower impact and crushing resistance. The mechanical properties of bituminous concrete with plain OBBA are usually inferior to those of bituminous concrete with natural stone aggregate. In a recent study it is found that the bituminous concrete mix with $4 \%$ cement coated OBBA shows considerable improvement in various mechanical properties of bituminous concrete mix compared to the plain OBBA concrete mix [3]. Similarly, the present study is extended to modify the OBBA properties by plastic coating of various percentages.

Use of brick aggregate in concrete preparation is not new to the engineers. In Germany during the post-Second World War period, it was necessary to satisfy an enormous demand for the supply of constructional materials along with the removal of debris of war for rebuilding the country. By using these rubbles and demolished aggregates, it was possible not only to reduce site clearing costs but also to meet the need for building materials [4]. Mazumder et al. find that the distorted bricks are stronger than normal burnt bricks. The Los Angeles abrasion value of distorted brick aggregate is below the maximum specified limit as mentioned in specifications. The water absorption of the distorted brick aggregate is also lower [5]. It is observed that dense graded picked brick aggregate bituminous mixes are as efficient as crushed stone aggregate bituminous mixes for use in the base course 
of bituminous pavement from the standpoint of stability, stiffness, deformation, and voids characteristics $[6,7]$. Through experiment, it is found that brick aggregate bituminous concrete mixes are suitable for use in the surface courses of bituminous concrete pavements from the standpoints of stability, stiffness, and deformation characteristics. But the bitumen content requirements of those mixes are much higher than those of natural aggregate mixes [8,9]. Several researchers study the properties of hot mix asphalt with precoated aggregate and found better results [10]. Use of plastic to modify the bitumen and also the use of plastic coated stone aggregate are being studied by the researchers to ascertain better results for the better performance of the road pavement. It is found that the properties like moisture damage, stability, and indirect tensile strength are improved due to presence of plastic [11-14].

If the thin plastic comes in contact with hot aggregate it fills up the pores in the aggregate and forms a thin film of plastic coating on the surface of the aggregate. Plastic coated OBBA becomes less porous and thus reduces water absorption to a great extent.

In this study plastic coated OBBAs are used to prepare the bituminous concrete mix. OBBAs are heated to a temperature of $190^{\circ} \mathrm{C}$ and shredded plastic bags are spread over the hot aggregates. In this temperature, the thin plastic pieces get softened and form a coating over the aggregate of about 90$95 \%$ of the surface area. Shredded waste plastic bags are mixed with OBBA in different percentages as $0.38,0.42,0.46,0.50$, 0.54 , and 0.60 of the weight of brick aggregates to improve the properties. The bituminous concrete mix with plastic coated OBBA shows considerable improvement in various mechanical properties of the mix compared to the plain OBBA. The basic objective of the study is to utilize the waste overburnt brick as well as waste plastic in an ecofriendly way. The main objective of the present study is to evaluate the plastic coated OBBA as an alternative material for bituminous road construction.

\section{Experiment}

\subsection{Material}

2.1.1. Bitumen. Bitumen is commonly known as asphalt cement or asphalt. It is mainly used as binder mixed with aggregate particles to form bituminous concrete. In this study, VG-30 grade bitumen has been used as binder to prepare the bituminous concrete mix. The penetration test of bitumen is carried out at a temperature of $25^{\circ} \mathrm{C}$. The properties of bitumen used in this study are presented in Table 1 and compared with the acceptable values mentioned in Indian Standard Codes [15-19].

2.1.2. Aggregates. Aggregates normally constitute 90-95 percent of the weight of the total mix. The function of aggregate in a bituminous concrete mix is to provide a rigid skeleton and to reduce the space occupied by the bitumen content and fines. Aggregates have certain physical properties which judge the suitability of aggregate for specific uses. The physical properties of aggregates generally refer to the structure
TABle 1: Properties of bitumen.

\begin{tabular}{lccc}
\hline Sl. number & $\begin{array}{c}\text { Test } \\
\text { performed }\end{array}$ & Test result & $\begin{array}{c}\text { Acceptable } \\
\text { values }\end{array}$ \\
\hline 1 & $\begin{array}{c}\text { Specific } \\
\text { gravity } \\
\text { Penetration } \\
(\mathrm{mm})\end{array}$ & 0.99 & $\begin{array}{c}0.99 \\
\text { (minimum) }\end{array}$ \\
3 & $\begin{array}{c}\text { Softening } \\
\text { point }\left({ }^{\circ} \mathrm{C}\right) \\
\text { Ductility } \\
(\mathrm{cm})\end{array}$ & 47 & $80-100$ \\
\hline & & 92 & $35-50$ \\
\hline
\end{tabular}

of the particles that form the aggregate. Though it is difficult to model directly the performance of bituminous mixture using aggregate properties, the properties like gradation, hardness, toughness, and porosity have major effects on the performance of bituminous mixture. Aggregate impact, Los Angeles abrasion, water absorption, and soundness test are carried out as per AASHTO T 96-02 (2015) and ASTM codes [20-23]. The test is carried out for stone, OBBA, and $0.38 \%$, $0.42 \%, 0.46 \%, 0.50 \%, 0.54 \%$, and $0.60 \%$ plastic coated OBBA. The results are tabulated in Table 2.

2.1.3. Stone Dust. The mineral fillers in a bituminous concrete mix consist of finely divided mineral matters such as rock dust, slag dust, hydrated lime, hydraulic cement, fly ash, loess, and other suitable mineral matters. Mineral fillers should have 100 percent of the particles passing $0.60 \mathrm{~mm}, 95$ to 100 percent passing $0.30 \mathrm{~mm}$, and 70 percent passing $0.075 \mathrm{~mm}$. In this study, stone dust has been used as mineral filler. The standard test method mentioned in ASTM code is followed [24]. The properties of stone dust, used in this study, are listed in Table 3.

2.1.4. Plastic. Plastic is an essential component of numerous consumer products. All kinds of plastic are not the same. They are usually synthetic and derived from petrochemicals, but few of them are partially natural too. Society of the Plastics Industry (SPI) classifies the different types of plastic as SPI Code numbers 1 to 7. Plastic with SPI code 1 is made of Polyethylene Terephthalate (PET) commonly used to make beverage bottles, medicine jars, combs, and so forth. Plastic with SPI code 2 is made of High-Density Polyethylene (HDPE) commonly used to make containers for milk, motor oil, and so forth. Plastic with SPI code 3 is made of polyvinyl chloride (PVC) commonly used to make PVC pipes. Plastic with SPI code 4 is made of Low-Density Polyethylene (LDPE) commonly used to make plastic cling wrap, sandwich bags, squeezable bottles, plastic grocery bags, and so forth. Plastic with SPI code 5 is made of polypropylene (PP) commonly used to make syrup bottles, stadium cups, and so forth. Plastic with SPI code 6 is made of polystyrene (PS) commonly used to make disposable coffee cups, packing foam, and so forth. Plastic with SPI code 7 is made of Polycarbonate (PC) and polylactide commonly used to make compact discs, medical storage containers, and so forth [25]. 
TABLE 2: Properties of aggregate.

\begin{tabular}{lcccccccc}
\hline \multirow{2}{*}{ Test performed } & \multirow{2}{*}{ Stone aggregate } & \multirow{2}{*}{ OBBA } & \multicolumn{5}{c}{ Plastic coated OBBA } \\
& & & $0.38 \%$ & $0.42 \%$ & $0.46 \%$ & $0.50 \%$ & $0.54 \%$ & $0.60 \%$ \\
\hline Aggregate impact value & $22.4 \%$ & $29.6 \%$ & 28.6 & $27.3 \%$ & $26.2 \%$ & $24.6 \%$ & $23.9 \%$ & 23.8 \\
Los Angeles abrasion value & $15.1 \%$ & $32 \%$ & 31.3 & $31.0 \%$ & $30.1 \%$ & $27.6 \%$ & $25.2 \%$ & 25.2 \\
Water absorption value & $0.96 \%$ & $6.6 \%$ & 5.9 & $5.3 \%$ & $4.9 \%$ & $3.5 \%$ & $2.9 \%$ & 2.5 \\
Specific gravity & 2.64 & 1.89 & 1.99 & 2.04 & 2.16 & 2.24 & 2.45 & 2.46 \\
\hline
\end{tabular}

TABLE 3: Properties of stone dust.

\begin{tabular}{lrc}
\hline Sl. number & Test performed & Test result \\
\hline 1 & Specific gravity & 2.7 \\
2 & Bulk density $\left(\mathrm{kN} / \mathrm{m}^{3}\right)$ & 18.1 \\
\hline
\end{tabular}

TABle 4: Properties of plastic.

\begin{tabular}{lcc}
\hline Type of material & Thickness $(\mu \mathrm{m})$ & Softening point \\
\hline Cup & 150 & $100-120^{\circ} \mathrm{C}$ \\
Parcel cover & 50 & $100-120^{\circ} \mathrm{C}$ \\
Carry bags & 10 & $100-120^{\circ} \mathrm{C}$ \\
Film & 50 & $100-120^{\circ} \mathrm{C}$ \\
\hline
\end{tabular}

Waste plastic carry bags are used in this study. Plastic carry bags are a type of shopping bags made from various kinds of plastic materials. Most of the carry bags are made up of Polyethylene (PE), Polypropylene (PP), and so forth. $\mathrm{PE}$ is the most popular and most widely used plastic all over the world. This material has wide range of properties with excellent fatigue and wear resistance. It has excellent impact resistance, low moisture absorption, and high tensile strength. The material is characterized by its thickness and softening temperature. The test results of plastic used in the study are tabulated in Table 4 .

\subsection{Methods}

2.2.1. Design of Bituminous Concrete Mix. Bituminous concrete is a composite material commonly used to surface roads in flexible pavement. It consists of mineral aggregate bound together with bitumen and compacted. Bituminous concrete is prepared by heating the bitumen in order to decrease its viscosity and to dry the aggregate in order to remove the moisture from it prior to mixing. In this study, the oven dried OBBAs are heated to $190^{\circ} \mathrm{C}$ temperature and then plastic shreds of size less than $2.36 \mathrm{~mm}$ are mixed on the aggregate. When the plastic shreds come in contact with the hot aggregate they melt and form a thin film on the surface of the aggregate. The coated aggregate is kept in room temperature for $24 \mathrm{hrs}$. The coated aggregate, mixed with hot bitumen in $150^{\circ} \mathrm{C}$ temperature, prepares the bituminous concrete mix. The bituminous concrete is characterized through different laboratory experiments [26].

Bituminous concrete mix is commonly designed by Marshall Method. In this method, the resistance to plastic deformation of cylindrical specimen of bituminous mixture is measured. The test procedure is used in the design and evaluation of bituminous paving mixes. In this present study, Marshall Test is performed with stone aggregate as well as with overburnt brick aggregate. The standard gradation of aggregate to prepare the test specimen, followed in this study as per MoRT\&H [27], is presented in Table 5. The main objective of the mix design is to find suitable bitumen content to prepare the concrete mix. The Marshall Method is used to determine the optimum bitumen content (OBC). Table 6 provides the standard values of Marshall Test results and tensile strength ratio (TSR) as specified by MoRT\&H. Test specimens have been prepared and tested in the laboratory according to MoRT\&H guidelines. From the test results the relationship of Marshall Stability, flow value, voids in mineral aggregate (VMA), air void (VA), and voids filled with bitumen (VFB) with varying percentages of bitumen content for stone aggregate, normal OBBA, and plastic coated OBBA has been studied. In this present study, $0.38 \%, 0.42 \%, 0.46 \%$, $0.50 \%, 0.54 \%$, and $0.60 \%$ plastic are added to the coarse aggregate for coating by weight of aggregate. The aggregates are heated to a temperature at $190^{\circ} \mathrm{C}$ and shredded plastic is added to the hot aggregate. The shredded plastic forms a coating over the hot aggregate. The plastic coated aggregate is used to prepare test specimen. The Marshall Test results, obtained in the laboratory for stone, OBBA, and coated OBBA, are displayed in Table 7.

2.2.2. Stripping Value Test. Stripping value test is the determination of binding strength of the aggregate and bitumen. Standard guideline as specified by IS: 6241-1971 is followed to complete the test. 200 gm of clean, oven dried aggregates passing $20 \mathrm{~mm}$ sieve and retained on $12.5 \mathrm{~mm}$ sieve is heated to $150^{\circ} \mathrm{C}$ and mixed with $5 \%$ bitumen by weight of aggregate which is preheated to $160^{\circ} \mathrm{C}$ before the preparation of mix $[28,29]$. It is tested by immersing bitumen coated aggregate in water for $24 \mathrm{hrs}$ at a temperature of $40^{\circ} \mathrm{C}$. When the bitumen coated aggregate is immersed in water, the water penetrates into the pores and fills the voids of the aggregates resulting in the peeling of bitumen. After $24 \mathrm{hr}$ the stripping is observed and the percentage of stripping is noted. Test is conducted for the mix with precoated aggregate of $0.38 \%, 0.42 \%, 0.46 \%$, $0.50 \%, 0.54 \%$, and $0.60 \%$ plastic by weight of OBBA. The results are tabulated in Table 8.

2.2.3. Indirect Tensile Strength Test. The indirect tensile strength (ITS) test is used to measure the tensile strength of the bituminous concrete which can be used to assess the fatigue behavior. The standard procedure as per ASTM D 6931 is followed to prepare the sample for the test as well as to measure the failure loads [30]. The ITS provides a measure 
TABLE 5: Gradation of aggregate for bituminous concrete.

\begin{tabular}{lcccc}
\hline Sieve in mm & \% passing by weight of specimen & Cumulative \% passing & Cumulative \% retained & \% of aggregate and mineral filler \\
\hline 19 & 100 & 100 & 00 & Coarse aggregate 38\% \\
13.2 & $90-100$ & 89.5 & 10.50 & 21.0 \\
9.5 & $70-88$ & 79.0 & 38.0 & Fine aggregate 55\% \\
4.75 & $53-71$ & 62.0 & 50.0 & 59.0 \\
1.18 & $42-58$ & 50.0 & 68.0 & 77.0 \\
0.60 & $34-48$ & 41.0 & 84.0 & \\
0.30 & $26-38$ & 32.0 & 93.0 & \\
0.15 & $18-28$ & 23.0 & 16.0 & \\
0.075 & $12-20$ & 7.00 & & \\
\hline
\end{tabular}

Mineral filler $7 \%$.

TABle 6: Design criteria as per MoRT\&H.

\begin{tabular}{|c|c|c|c|c|c|c|c|c|}
\hline $\begin{array}{l}\text { Test } \\
\text { performed }\end{array}$ & $\begin{array}{c}\text { Minimum stability } \\
\left(\text { at } 60^{\circ} \mathrm{C}\right)\end{array}$ & Flow $(\mathrm{mm})$ & $\begin{array}{l}\text { Compaction } \\
\text { level (both } \\
\text { sides) }\end{array}$ & Air void & $\begin{array}{c}\text { VMA } \\
\text { (minimum) }\end{array}$ & VFB & $\begin{array}{l}\text { Marshall } \\
\text { Quotient } \\
(\mathrm{kN} / \mathrm{mm})\end{array}$ & $\begin{array}{c}\text { Tensile } \\
\text { strength ratio } \\
\text { (minimum) }\end{array}$ \\
\hline Results & $9 \mathrm{kN}$ & $2-4$ & 75 & $3-5 \%$ & $10 \%$ & $65-75 \%$ & $2-5$ & $80 \%$ \\
\hline
\end{tabular}

TABLE 7: Marshall Test results on different aggregate.

\begin{tabular}{|c|c|c|c|c|c|c|c|c|}
\hline \multirow{2}{*}{ Properties } & \multirow{2}{*}{ Stone } & \multirow{2}{*}{ OBBA } & \multicolumn{6}{|c|}{ Plastic coated OBBA } \\
\hline & & & $0.38 \%$ & $0.42 \%$ & $0.46 \%$ & $0.50 \%$ & $0.54 \%$ & 0.60 \\
\hline OBC (\%) & 05.10 & 9.4 & 9.0 & 8.8 & 8.3 & 8.0 & 8.0 & 8.0 \\
\hline Unit weight $\left(\mathrm{kN} / \mathrm{m}^{3}\right)$ & 24.1 & 23.0 & 23.1 & 23.2 & 23.3 & 23.7 & 23.9 & 24.0 \\
\hline Marshall Stability (kN) & 17.50 & 8.5 & 9.8 & 10.6 & 11.8 & 12.4 & 13.3 & 13.4 \\
\hline Flow $(\mathrm{mm})$ & 3.90 & 3.1 & 3.29 & 3.5 & 3.75 & 3.82 & 3.9 & 4.2 \\
\hline$\%$ of VA & 4.12 & 4.88 & 4.90 & 4.91 & 4.95 & 5.0 & 5.0 & 5.2 \\
\hline$\%$ of VMA & 14.27 & 21.9 & 21.7 & 21.6 & 20.4 & 20.1 & 19.9 & 18.6 \\
\hline$\%$ of VFB & 68.00 & 83 & 80.1 & 79 & 78.1 & 74.4 & 74.2 & 74.1 \\
\hline Marshall Quotient $(\mathrm{kN} / \mathrm{mm})$ & 4.49 & 2.74 & 2.98 & 3.02 & 3.15 & 3.24 & 3.41 & 3.27 \\
\hline
\end{tabular}

TABLE 8: Stripping value test results.

\begin{tabular}{lcc}
\hline Sl. number & $\begin{array}{c}\text { Plastic for } \\
\text { coating } \\
\text { aggregate used } \\
\text { in the mix }\end{array}$ & Stripping (\%) \\
\hline 1 & $0.38 \%$ & 9 \\
2 & $0.42 \%$ & 5 \\
3 & $0.46 \%$ & 2.5 \\
4 & $0.5 \%$ & 0 \\
5 & $0.54 \%$ & 0 \\
6 & $0.60 \%$ & 0 \\
\hline
\end{tabular}

of the tensile strength of the bituminous mixes. The test is conducted on the conditioned and unconditioned samples. Three samples are kept in freezer for 16 hours and then placed in a water bath for $24 \mathrm{hrs}$ at a temperature of $60^{\circ} \mathrm{C}$. These samples are considered as conditioned samples. Another 3 samples are kept unconditioned. The sample is tested in the Marshall Stability testing equipment. The indirect tensile strength results are presented in Table 9.

2.2.4. Resilient Modulus Test. Resilient modulus (RM) of bituminous concrete mix is an important parameter for flexible pavement design and evaluation. It is defined as the ratio of the repeated stress to the corresponding resilient strain. The resilient modulus of a tested sample is calculated from the following equation:

$$
E_{\mathrm{RT}}=\frac{P\left(V_{\mathrm{RT}}+0.27\right)}{t \Delta H_{T}},
$$

where $P$ is the repeated load in $\mathrm{N}, V_{\mathrm{RT}}$ is the total Resilient Poisson ratio generally taken as $0.35, t$ is the thickness of specimen in $\mathrm{mm}$, and $\Delta H_{T}$ is the total recoverable horizontal deformation in $\mathrm{mm}$. The test is performed according to ASTM D 7369-11 [31].

2.2.5. Wheel Tracking Test. Rutting is a longitudinal depression on groove in the wheel tracks. The ruts are formed according to the width of the wheel path. Pavement rutting 
TABLE 9: Indirect tensile strength test results.

\begin{tabular}{lcccc}
\hline Sl. number & Plastic \% for coating of OBBA & \multicolumn{2}{c}{$\begin{array}{c}\text { The indirect tensile strength }\left(\mathrm{N} / \mathrm{mm}^{2}\right) \\
\text { Unconditioned }\end{array}$} & $\begin{array}{c}\text { Tensile strength ratio (\%) } \\
\text { Conditioned }\end{array}$ \\
\hline 1 & $0.38 \%$ & 0.86 & 0.63 & 73.00 \\
2 & $0.42 \%$ & 1.06 & 0.99 & 77.36 \\
3 & $0.46 \%$ & 1.24 & 1.04 & 81.25 \\
4 & $0.50 \%$ & 1.28 & 1.08 & 82.44 \\
5 & $0.54 \%$ & 1.31 & 1.08 & 81.81 \\
\hline
\end{tabular}

not only decreases the service life of the roads but also creates perils for the road users. Rutting characteristics are studied using immersion wheel tracking device. Wheel tracking test is widely used for evaluating the rutting potential of pavements. In this method, a steel wheel with solid rubber tire is rolled to and fro over the specimen of bituminous surface of size $600 \mathrm{~mm} \times 200 \mathrm{~mm} \times 50 \mathrm{~mm}$ to test the rutting potential and then rutting depth is measured up to 8000 passes [32].

2.2.6. Fatigue Life Test. Repeated load test is conducted using fatigue testing machine developed by Geotran, New Delhi. An attempt is made to study the performance of bituminous concrete with plain and $0.54 \%$ plastic coated brick aggregate mix under the applied loads, $2 \mathrm{kN}, 3 \mathrm{kN}$, and $4 \mathrm{kN}$, respectively, and frequency $5 \mathrm{~Hz}$ with sinusoidal type of waveform is applied at temperatures between $35^{\circ} \mathrm{C}$ and $37^{\circ} \mathrm{C}$ $[33,34]$. Three specimens are tested for each case.

\section{Results and Discussion}

3.1. Marshall Stability, Flow, and Marshall Quotient Properties. The results of Marshall Test show that the stability of the mix increases in equal proportion with the increase of the amount of plastic in the OBBA. At $0.60 \%$ plastic coating the value reaches up to $13.4 \mathrm{kN}$. But the flow value for such mix is 4.2 which is more than the highest permissible value 4.0 as mentioned in Table 6 . At $0.54 \%$ plastic coating the value reaches up to $13.3 \mathrm{kN}$ which is very close to the highest value of $13.4 \mathrm{kN}$. The flow value is also within limit for such mix. Hence, in this study, $0.54 \%$ plastic coating is considered as optimum plastic content for coating of OBBA. The volumetric properties of this mix at different binder content versus stability, flow, air voids, bulk density, void filled with bitumen, and void in mineral aggregate are presented graphically in Figure 1 . The stability of such mix increases by $56 \%$ compared to normal OBBA and decreases by $31.82 \%$ compared to stone. However, mixes with very high Marshall Stability values and low flow values are not desirable as the pavements, constructed with such mixes, may be brittle and are likely to develop cracks due to heavy vehicular traffic. This study also shows that Marshall Quotient value of the mix is also effective for mix with $0.54 \%$ plastic coated OBBA.

3.2. Resistance to Moisture Susceptibility. Stripping value reduces with the increase in the percentage of plastic coating. Stripping value is least when the percentage of plastic coating is 0.50 and $0.54 \%$, respectively. It also satisfies the acceptable value (as per Table 6 ). Hence $0.54 \%$ plastic coated aggregate shows a better binding strength with bitumen even when it is subjected to the worst moisture content. The coating of molten-plastic over the aggregate reduces water absorption. This shows that the voids on the surface are reduced. The fewer the voids the better the quality of the aggregate. The presence of entrapped air in the voids of aggregates causes oxidation of bitumen which results in stripping and formation of potholes. Thus, the plastic coated aggregate with fewer voids is considered as a better road construction material.

3.3. Indirect Tensile Strength. Bituminous pavement surface can develop distress due to fatigue. It is caused by tensile strains generated in the pavement not only by traffic loading but also by temperature variation. If the tensile strength is higher and the tensile strength ratio is within the permissible limit, in another way, it can be said that bitumen concrete mix is safe against fatigue. From Table 8 , it is noticed that the indirect tensile strength (ITS) increases with the increase in the amount of plastic content. The ITS value reaches a peak value at $0.54 \%$ plastic coating and then it falls in both conditioned and unconditioned cases. Highest ITS value is $1.31 \mathrm{~N} / \mathrm{mm}^{2}$ for the same plastic content and corresponding tensile strength ratio (TSR) is $82.44 \%$ which is acceptable (as per Table 6). Thus, $0.54 \%$ plastic coated OBBA mix is safer against fatigue.

3.4. Resilient Modulus Test. The test is performed at different temperatures such as $5^{\circ} \mathrm{C}, 25^{\circ} \mathrm{C}, 35^{\circ} \mathrm{C}$, and $45^{\circ} \mathrm{C}$. The test results for resilient modulus test, obtained in the study, are shown in Figure 2 for the mix without plastic coated brick aggregate and for the mix with $0.54 \%$ plastic coated brick aggregate.

3.5. Wheel Tracking Test. In the present study, the stress that the wheel applies to the specimen is $0.70 \mathrm{MPa}$. Two LVDTs (Linear Variable Differential Transducers) are fitted to the axle of the rubber wheel to monitor the rut depth. The output of the LVDT is connected to a computer. Dedicated software monitors the rut depth and plots the graph for number of passes versus rut depth. The wheel tracking results are shown in Figure 3. The rutting is found lower in case of bituminous concrete mix containing $0.54 \%$ plastic coating in comparison to the $0 \%$ plastic coating. 

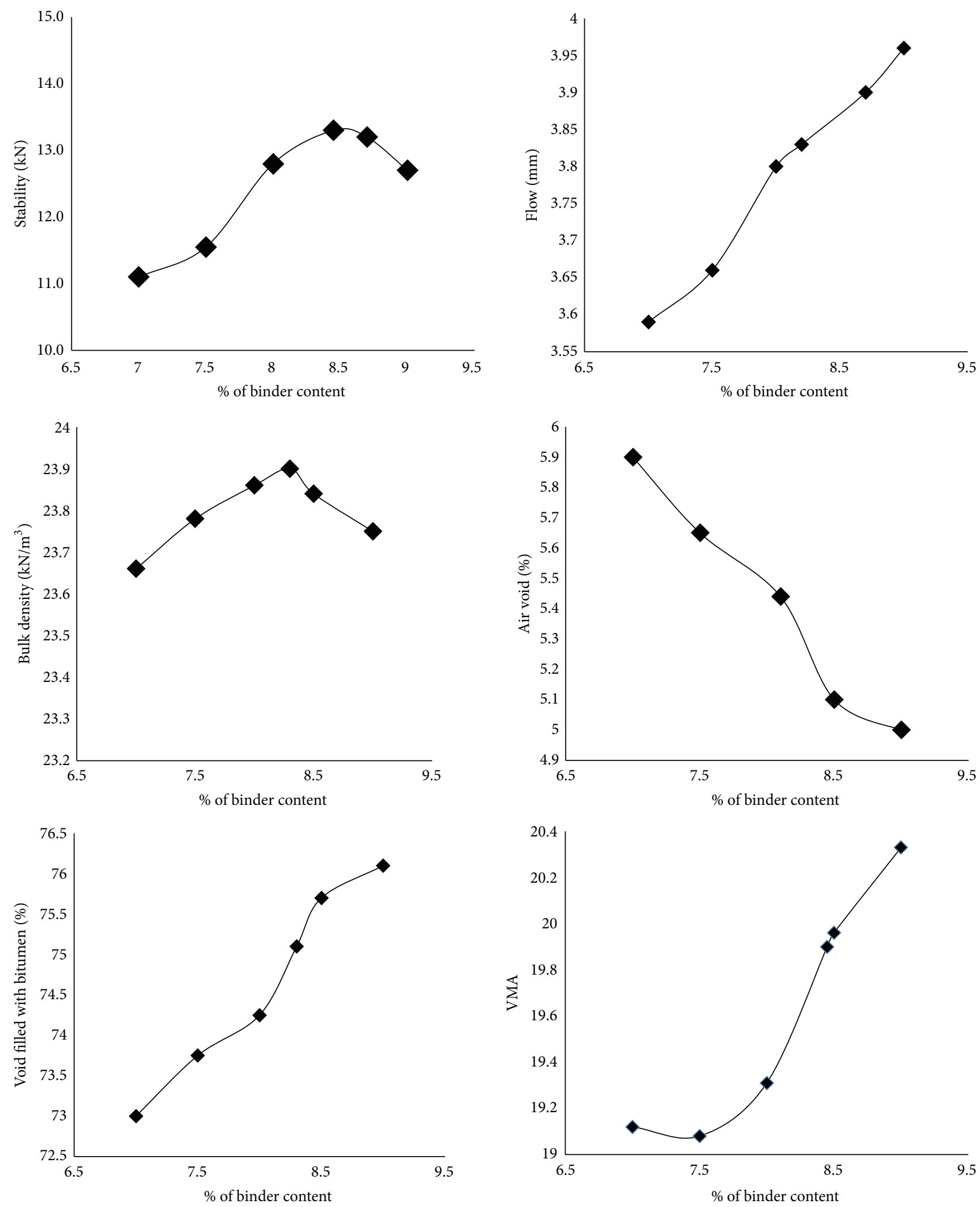

FIGURE 1: Volumetric properties of bituminous concrete mix (using $0.54 \%$ plastic coated OBBA) at binder content versus stability, flow, air voids, bulk density, voids filled with bitumen, and void in mineral aggregate. 


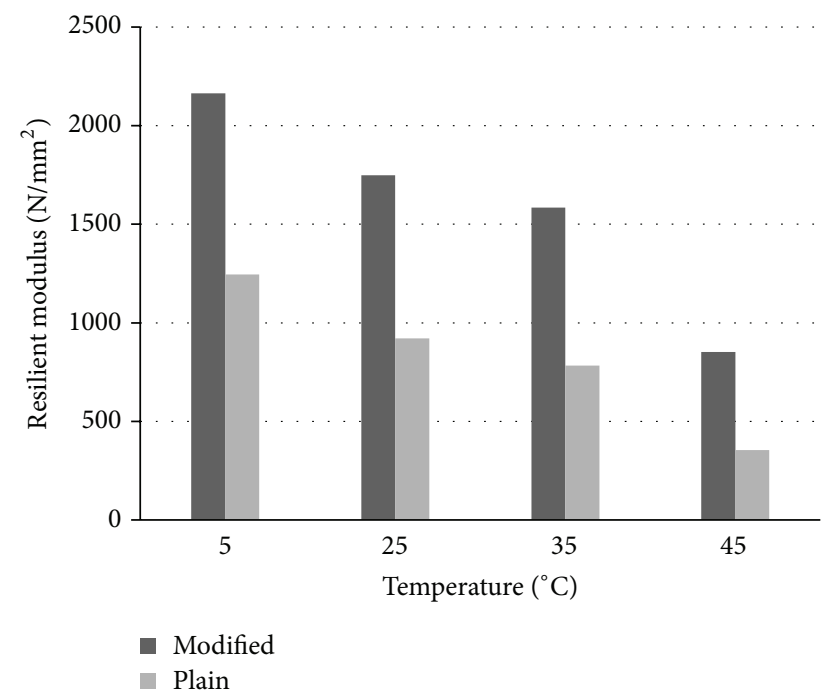

FIGURE 2: Resilient modulus values for the mix plain and modified aggregate (plastic coated).

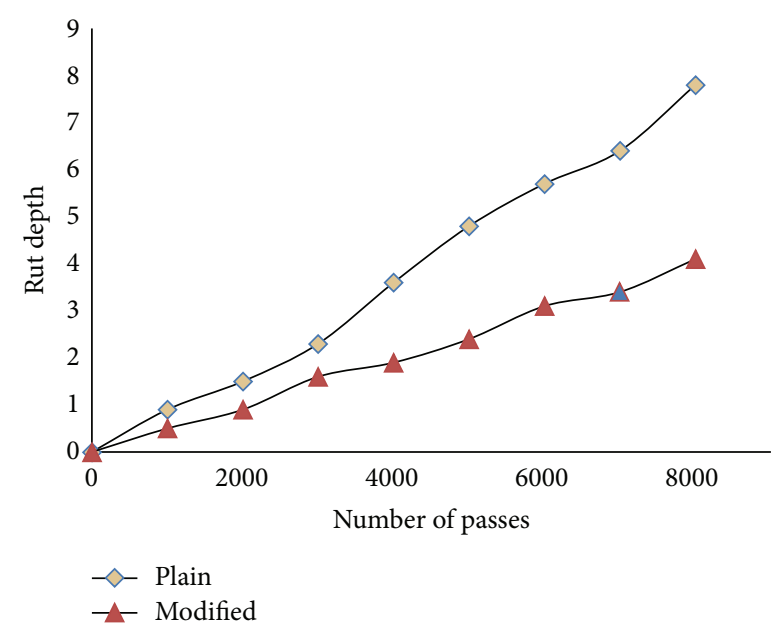

FIgURE 3: Rut depth versus number of passes.

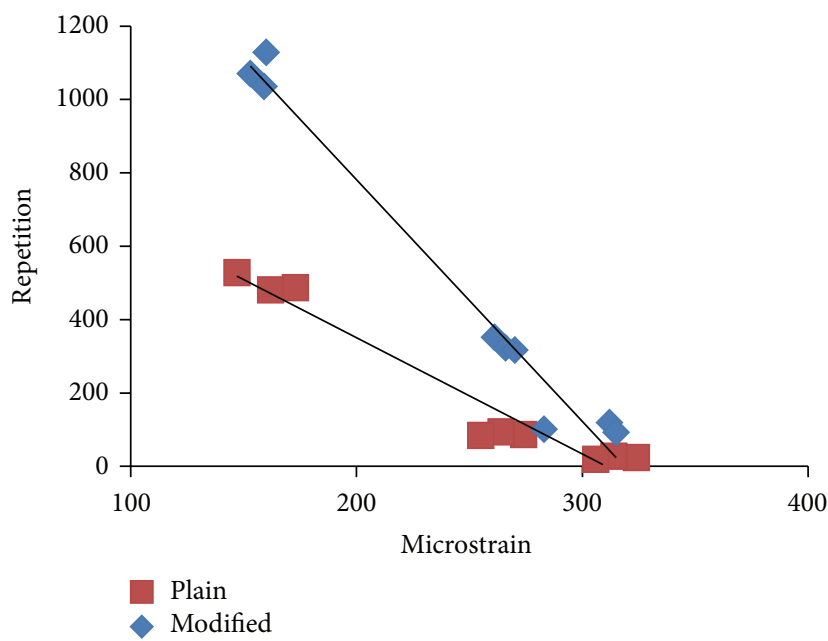

FIGURE 4: Tensile strain versus number of repetitions.
3.6. Fatigue Life Test. The test result shows that the fatigue life of bituminous concrete with plastic coated brick aggregate is much higher than that of bituminous concrete with plain brick aggregate mix with equal tensile strain. This is due to the hardness of aggregate mix with plastic coating. Figure 4 indicates that, for a given tensile strain $\varepsilon_{t}$ of $200 \times 10^{-6}$, the corresponding fatigue life of bituminous concrete of plain and modified brick aggregate is 355 and 765, respectively. Thus, it is concluded that the fatigue life of bituminous concrete mix with $0.54 \%$ plastic coated brick aggregate improves by a factor of 2.15. This clearly indicates that BC mix with $0.54 \%$ plastic coated aggregate is capable of tolerating higher strain and taking higher number of repetitions prior to failure. The present investigation positively proves that bituminous concrete mix with $0.54 \%$ plastic coated aggregate is expected to have much longer fatigue life compared to the bituminous concrete mix with plain brick aggregate mix.

\section{Conclusion}

The results of the study reveal that the $0.54 \%$ waste plastic coated brick aggregate shows better performance as road aggregate. From this study, the following conclusions can be drawn:

(1) The stability of the bituminous concrete mix with $0.54 \%$ plastic coated brick aggregate is $56 \%$ higher than the mix with plain brick aggregate.

(2) Moisture susceptibility of the mix with modified aggregate is lesser than the plain mix.

(3) The TSR value for the mix with modified aggregate is $9.44 \%$ higher than mix with plain brick aggregate which indicates the improvement in the moisture sensitivity of the mix.

(4) Resilient modulus of the mix with $0.54 \%$ plastic coated brick aggregate at $35^{\circ} \mathrm{C}$ is $102 \%$ higher than the plain mix which indicates the higher stiffness of the mix.

(5) Rutting failure for the mix with $0.54 \%$ plastic coated brick aggregate is lesser than the plain mix and it points out that the failure for this mix may take place at later stage.

(6) Fatigue life of the mix with modified brick aggregate is also higher.

Thus, plastic coated overburnt brick aggregate can be used as an alternative material for bituminous road construction.

\section{Competing Interests}

The authors declare that they have no competing interests.

\section{References}

[1] R. Vasudevan, A. Ramalinga Chandra Sekar, B. Sundarakannan, and R. Velkennedy, "A technique to dispose waste plastics in an ecofriendly way-application in construction of flexible pavements," Construction and Building Materials, vol. 28, no. 1, pp. 311-320, 2012. 
[2] M. A. Mansur, T. H. Wee, and S. C. Lee, "Crushed Bricks as Coarse aggregate for concrete," ACI Materials Journal, vol. 96, no. 4, pp. 478-484, 1996.

[3] D. Sarkar and M. Pal, "Effect of cement on properties of over-burnt brick bituminous concrete mixes," Journal of The Institution of Engineers: Series A, vol. 97, no. 2, pp. 163-170, 2016.

[4] C. S. Poon and D. Chan, "Paving blocks made with recycled concrete aggregate and crushed clay brick," Construction and Building Materials, vol. 20, no. 8, pp. 569-577, 2006.

[5] A. R. Mazumder, A. Kabir, and N. Yazdani, "Performance of overburnt distorted bricks as aggregates in pavement works," Journal of Materials in Civil Engineering, vol. 18, no. 6, pp. 777785, 2006.

[6] F. Debieb and S. Kenai, "The use of coarse and fine crushed bricks as aggregate in concrete," Construction and Building Materials, vol. 22, no. 5, pp. 886-893, 2008.

[7] M. A. Sobhan and M. Zakaria, "Experimental behaviour of bituminous macadam mixes with brick aggregate," Journal of Civil Engineering, Institution of Civil Engineers, Bangladesh, vol. 29, no. 1, pp. 115-123, 2001.

[8] A. M. Haque, Behavior of brick aggregate asphaltic concrete for road pavement [M.Sc. Engineering thesis], BUET, 1976.

[9] H. M. Rasel, M. A. Sobhan, and M. N. Rahman, "Performance evaluation of brick chips as coarse aggregate on the properties of bituminous mixes," SAMRIDDHI, vol. 2, no. 2, pp. 37-46, 2011.

[10] C.-H. Lee, J.-C. Du, and D.-H. Shen, "Evaluation of pre-coated recycled concrete aggregate for hot mix asphalt," Construction and Building Materials, vol. 28, no. 1, pp. 66-71, 2012.

[11] VS. Punith and A. Veeragaran, "Fatigue characteristic of recycled plastics modified bituminous concrete mix," IRC 70, Indian Highways, 2004.

[12] A. V. Ravi Shankar, K. Koushik, and G. Saramg, "Performance studies on Bituminous concrete mixes using waste Plastics," IRC, Highway Research Journal, pp. 1-12, 2013.

[13] F. M. Nejad, M. Arabani, G. H. Hamedi, and A. R. Azarhoosh, "Influence of using polymeric aggregate treatment on moisture damage in hot mix asphalt," Construction and Building Materials, vol. 47, pp. 1523-1527, 2013.

[14] M. T. Awwad and L. Shbeeb, "The use of polyethylene in hot asphalt mixtures," American Journal of Applied Sciences, vol. 4, no. 6, pp. 390-396, 2007.

[15] IS 1208, Bureau of Indian Standard, Methods for testing tar and bituminous materials, determination of Ductility, India, 1978.

[16] IS, "Methods for testing tar and bituminous materials, determination of penetration, India," IS 1203:1978, Bureau of Indian Standard, 1978.

[17] IS 1202, Bureau of Indian Standard, Methods for testing tar and bituminous materials, determination of specific gravity, India, 1978.

[18] IS 1205, Bureau of Indian Standard, Methods for testing tar and bituminous materials, determination of softening point, India, 1978.

[19] IS 73, Indian standard paving bitumen-specification, 2nd Revision, Bureau of Indian Standards, 1992.

[20] AASHTO, "Standard method of test for resistance to degradation of small-size coarse aggregate by abrasion and impact in the Los Angeles machine," AASHTO T 96-02, 2015.

[21] ASTM, "Standard test method for density, relative density (specific gravity) and absorption of coarse aggregate," ASTM C127-15, ASTM, West Conshohocken, Pa, USA, 2015.
[22] ASTM, "Standard test method for resistance to degradation of large size coarse aggregate by abrasion and impact in the LosAngeles machine, USA," Tech. Rep. ASTM C535-12, 2012.

[23] ASTM, "Standard test method for resistance to degradation of small size coarse aggregate by abrasion and impact in the LosAngeles machine, USA, Tech. Rep. ASTM C131-06, 2006.

[24] ASTM, "Standard test method for relative density (specific gravity) and absorption of fine aggregate," ASTM C128-15, ASTM, West Conshohocken, Pa, USA, 2015.

[25] SPI Plastic Engineering Handbook, Springer, Berlin, Germany, 1991.

[26] ASTM, "Standard test method for marshall stability and flow of asphalt mixtures," ASTM D6931-12, ASTM International, West Conshohocken, Pa, USA, 2012.

[27] Ministry of Road Transport and Highways (MoRT\&H), Specification for Roads and Bridge Works, IV Revision, Indian Road Congress, New Delhi, India, 2013.

[28] IS, "Methods for test for determination of stripping value of road aggregates," IS 6241:1971, Bureau of Indian Standard, New Delhi, India, 1971.

[29] F. M. Nejad, A. R. Azarhoosh, G. H. H. Hamedi, and M. J. Azarhoosh, "Influence of using nonmaterial to reduce the moisture susceptibility of hot mix asphalt," Construction and Building Materials, vol. 31, pp. 384-388, 2012.

[30] ASTM, "Standard test method for Indirect Tensile (IDT) strength of bituminous mixtures," ASTM D6931-12, ASTM, West Conshohocken, Pa, USA, 2012.

[31] ASTM, "Standard test method for determining the resilient modulus of bituminous mixtures by indirect tension test," ASTM D7369-11, ASTM International, West Conshohocken, Pa, USA, 2011.

[32] V. B. Kakade and M. A. Reddy, "Effect of type and quantity of binder on rutting characteristics of bituminous mix," Indian Highways, vol. 42, no. 3, pp. 8-14, 2014.

[33] X. Shu, B. Huang, and D. Vukosavljevic, "Laboratory evaluation of fatigue characteristics of recycled asphalt mixture," Construction and Building Materials, vol. 22, no. 7, pp. 1323-1330, 2008.

[34] G. G. Al-Khateeb and K. A. Ghuzlan, "The combined effect of loading frequency, temperature, and stress level on the fatigue life of asphalt paving mixtures using the IDT test configuration," International Journal of Fatigue, vol. 59, pp. 254-261, 2014. 

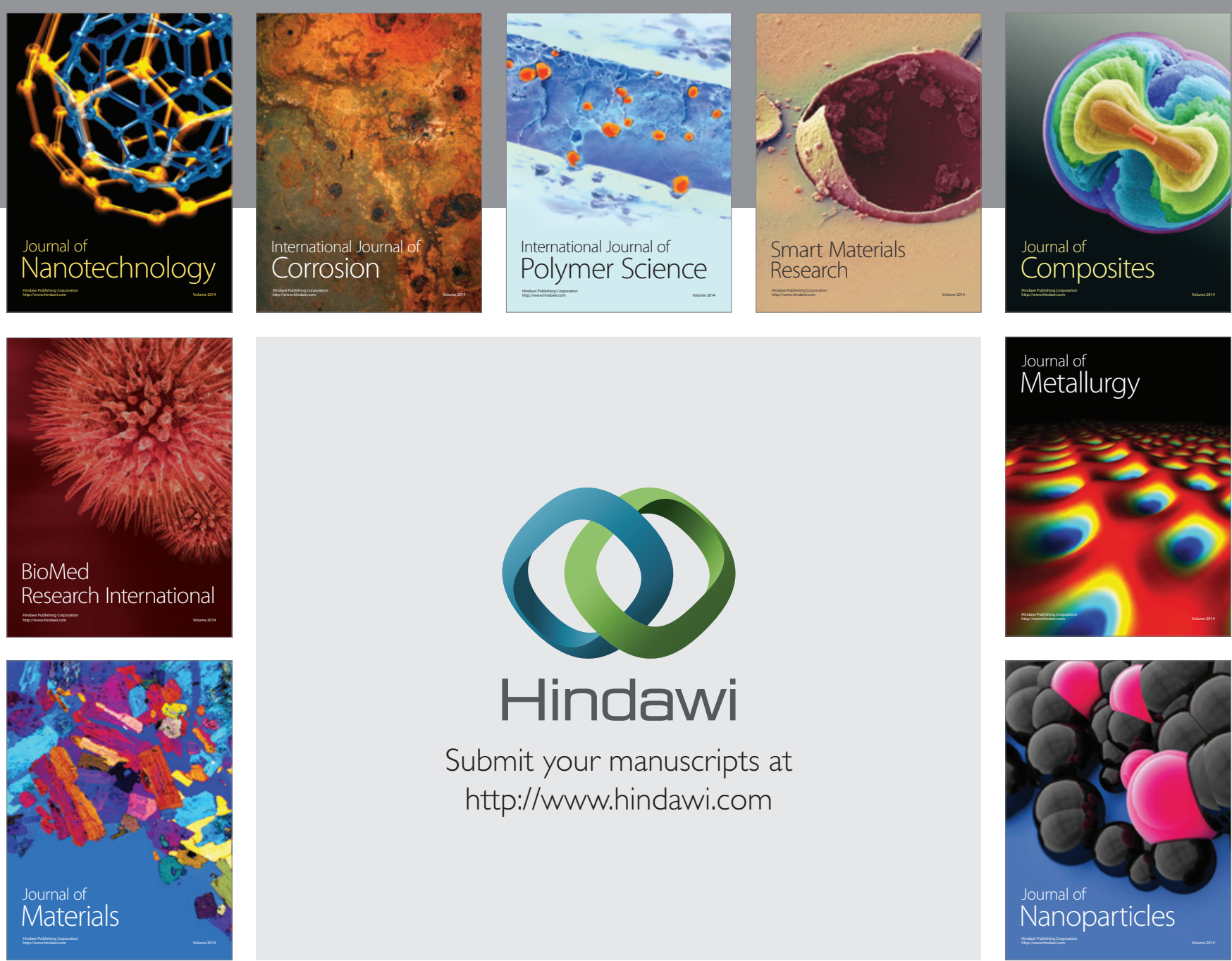

\section{Hindawi}

Submit your manuscripts at

http://www.hindawi.com

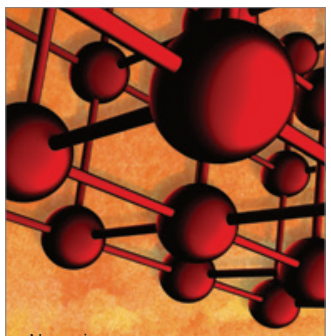

Materials Science and Engineering
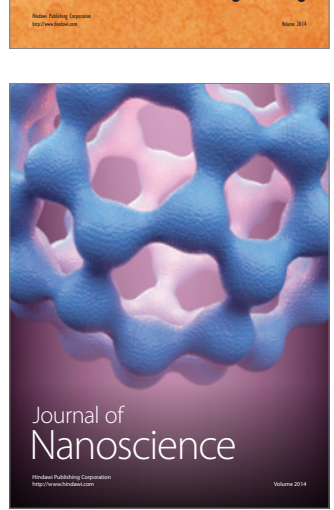
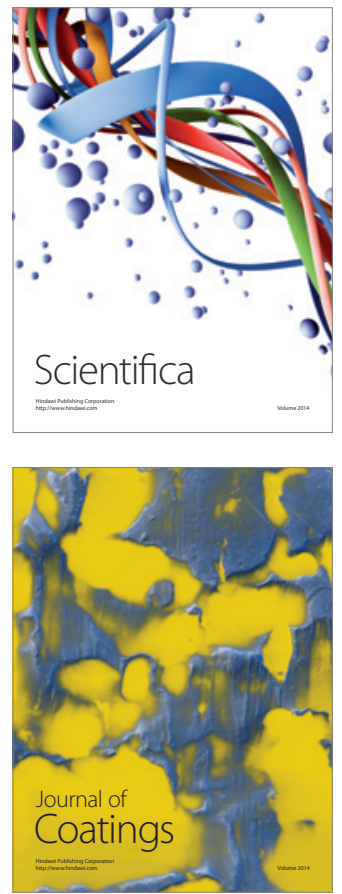
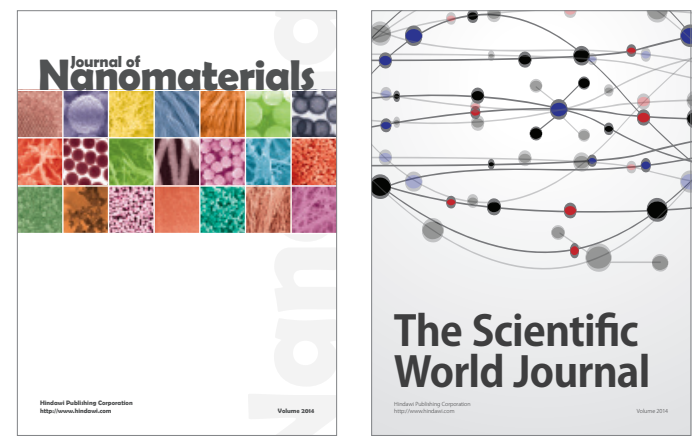

The Scientific World Journal
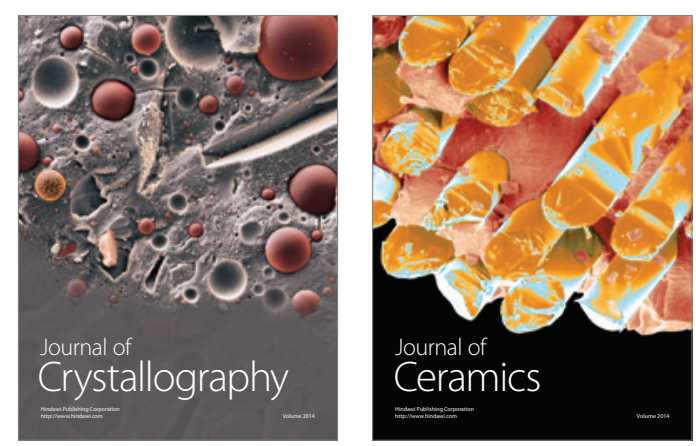
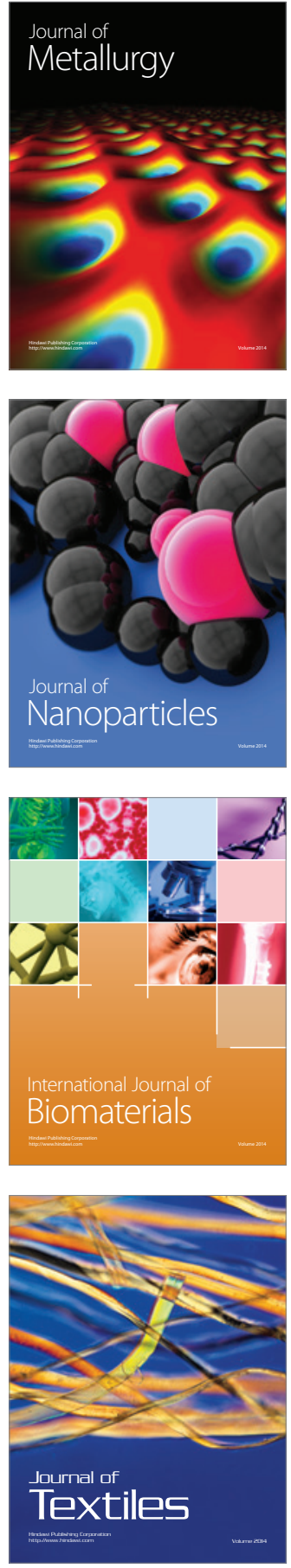